\title{
CONULARIID TAPHONOMY AS A TOOL IN PALEOENVIRONMENTAL ANALYSIS
}

\author{
MARCELLO GUIMARÃES SIMÕES ${ }^{1}$, LUIZ HENRIQUE CRUZ DE MELLO ${ }^{1}$, SABRINA COELHO RODRIGUES ${ }^{1}$, \\ JULIANA DE MORAES LEME ${ }^{1} \&$ ANTONIO CARLOS MARQUES ${ }^{2}$
}

\begin{abstract}
RESUMO TAFONOMIA DE CONULÁRIOS COMO UM CRITÉRIO EM ANÁLISE PALEOAMBIENTAL Na seqüência devoniana da Bacia do Paraná, conularí́deos (Cnidaria) são elementos conspícuos nos sedimentos da parte basal da Formação Ponta Grossa (LochkovianoFrasniano). Sua preservação parece estar associada à circunstâncias não usuais. De fato, os sedimentos fossilíferos ricos em restos de conularídeos foram depositados sob condiçóes plataformais ou de águas rasas, em mar epicontinental, pontuado por eventos de tempestades. $O$ exame de 28 blocos orientados $\left(\sim 5400 \mathrm{~cm}^{3}\right)$ de siltitos e argilitos, incluindo 29 espécimes de conularídeos, indica que esses foram fossilizados, de acordo com os seguintes modos de preservação: Conularí́deos orientados verticalmente (1), com a abertura para cima, $90^{\circ}-70^{\circ}$ em relação ao plano de acamamento, em siltitos maciços ou ligeiramente bioturbados, conularí́deos inclinados (2), com a abertura para cima, $\leq 60^{\circ}$ em relação ao plano de acamamento ou conularídeos orientados horizontalmente (3) em siltitos ou argilitos intensamente bioturbados, às ves, ricos em icnós situ. Desse modo, o hábito de vida de epifauna é inferido para esses invertebrados. Os espécimes orientados horizontalmente correspondem a elementos retirados de sua posição de vida, particularmente pela atividade biológica dentro do substrato, durante e logo após a deposição de sedimentos associados à tempestades. Espécimes orientados verticalmente, diretamente adjacentes a conularí́deos horizontalmente dispostos, em zonas de intensa bioturbacão corroboram essa idéia. Nesse caso, mesmo os espécimes orientados horizontalmente são indicadores confiáveis de mudan das nas inorgânicas estão faltando ou foram completamente destruídas ou obliteradas pela atividade biológica no interior do substrato. Finalmente, os sedimentos da parte basal da Formação Ponta Grossa, ricos em conulariídeos, são aqui interpretados como tempestitos.
\end{abstract}

Palavras-chaves: Tafonomia, Bioestratinomia, Conulários, Devoniano, Bacia do Paraná

\begin{abstract}
In the Devonian sequence of the Paraná Basin conulariids (Cnidaria) are conspicuous elements in sediments of the basal portion of the Ponta Grossa Formation (Lochkovian-Frasnian). Their preservation seems to be associated to unusual preservational circumstances. In fact the fossiliferous sediments rich in conulariids were deposited under platformal or shallow water conditions in a muddy epeiric sea, pu, punt indicates that they are preserved according to the following preservational modes: Vertically oriented conulariids (1) with aperture-up, $90^{\circ}-70^{\circ}$ to the bedding plane, in massive or less bioturbated siltstones, inclined (2) or horizontally oriented conulariids (3) in a completely bioturbated siltstone or mudstones, rich in Zoophycos. Vertically oriented specimens are interpreted as autochthonous elements, indicating the abrupt burial of living invertebrates. Thus, an attached epifaunal mode of life is inferred for these specimens. Horizontally oriented specimens correspond to disrupted elements, particularly by the biological activity within the substrate, during and after the rapid sediment deposition, associated to to disrupted elements, particularly by the biological activity within the substrate, during and after the rapid sedilition of intense sediment bioturbation support this idea. In this case, even the horizontally oriented specimens are reliable indicators of changes in siliciclastic accumulation rates, in tempestite proximality, and postmortem alteration by biological agents, specially when the inorganic primary sedimentary structures are lacking or were completely destroyed or obliterated by the biological activity in the substrate. The sediments rich in conulariids are interpreted here as tempestite beds.
\end{abstract}

Keywords: Taphonomy, Biostratinomy, Conulariid, Devonian, Paraná Basin

\section{INTRODUCTION}

Conulariids are extinct marine organisms having a four-side elongated pyramidal exoskeleton of calcium phosphate and protein, varying from three to four centimeters tall up to more than 30 centimeters, exceptionally (Babcock \& Feldmann 1984, 1986a, b, c, Babcock et al. 1987b, Babcock 1991). They were scattered through Paleozoic epeiric seas, being conspicuous elements of the Silurian and Devonian platformal faunal associations. Because of its unique evolutionary lineage ( $c f$. Jerre 1994) and particular mode of fossilization (see also Babcock et al. 1987b), conulariids raise fascinating questions, since the discovery of a specimen is an exciting opportunity to infer not only on the history and habits of an extinct invertebrate group (paraphrased from Babcock \& Feldmann 1984), but also about the taphonomic events responsible for their preservation.

In South America, conulariids can be important components of the Paleozoic fossil record, as exemplified by the classical occurrences of the Devonian "Conularia shales" from Bolivia (Babcock et al. 1987a, b). Less spectacular are, however, the Silurian (Babcock et al. 1990), Carboniferous (Mariñelarena 1970, Sabattini 1986) and Permian (Babcock 1988) occurrences in Paraguay, Argentina and Bolivia, respectively. Other important finds include those from the Devonian sediments of the Amazon Basin (Clarke 1899, Oliveira \& Leonardos 1943, Machado \& Fonseca 1997) and Paraná Basin (Clarke 1913).

The purpose of this paper is to present the first taphonomic study of conulariids from South America. They were found in Devonian sediments of Paraná Basin, Ponta Grossa Formation (LochkovianFrasnian). Until now, only a few brief references had appeared in the literature concerning these invertebrates (e.g., Petri \& Fúlfaro 1983, Cooper 1977, Melo 1988, Ciguel 1989), because previous paleontological studies of the Devonian sequence of the Paraná Basin have targeted other macrofossils, such as bivalves (Kotzian 1995, Machado 1999), trilobites (Popp 1985), brachiopods (Quadros 1987, Bosetti 1989) and tentaculits (Ciguel 1989). Surprisingly, the taphonomic data presented here show that the preservation of the Ponta Grossa conulariids seems to be associated to unusual sedimentologic circumstances, also furnishing new insights about their mode of life. In other words, our taphonomic study can furnish critical data for the understanding of the paleobiology of an extinct group, as well as in the recognizance of high-energy events (storms) and its periodicity in sedimentary sequences deposited in a siliciclastic epeiric sea.

GEOLOGIC AND STRATIGRAPHIC SETTING Conulariids occur in Devonian sediments of Paraná Basin, a huge intracratonic depression generated during the Early Paleozoic (Zalán et al. 1991), covering large portions of Brazil, Uruguay, Paraguay and Argentina. In its Brazilian portion, the Paraná Basin covers an area of more than 1 million $\mathrm{km}^{2}$ being filled by a thick siliciclastic Paleozoic and Mesozoic sedimentary sequence, also including extensive Cretaceous basaltic horizons (Schneider et al.1974). These rocks are included in five major unconformity-bounded sequences (Zalán et al. 1991). The Precarboniferous (Silurian-Devonian) rocks of the Apucarana subbasin, Paraná Basin, are attributed to the Furnas and Ponta Grossa Formations. These are constituted by six $3^{\text {rd }}$ order depositional sequences (Pereira et al. 1998, Bergamaschi 1999, also see Zalán et al. 1991, Assine et al. 1994, for a different chronolithostratigraphic division of the studied interval) (Fig. 1). Deposits of the Furnas and Ponta Grossa Formations can be grouped in the same depositional $\left(2^{\text {nd }}\right.$ order cycle) sequence (Bergamaschi 1999). In this context, the deltaic, transitional and shallow-marine deposits (Sequence A) of the Furnas Formation constitute the lowstand system tract, whereas the stormdominated shoreface and shallow-marine deposits (Sequence B), the shoreface sandy bodies (Sequences C, D, E), and shallow outer shelf deposits (Sequence F) of the Ponta Grossa Formation constitutes the transgressive system tract (Bergamaschi 1999). 


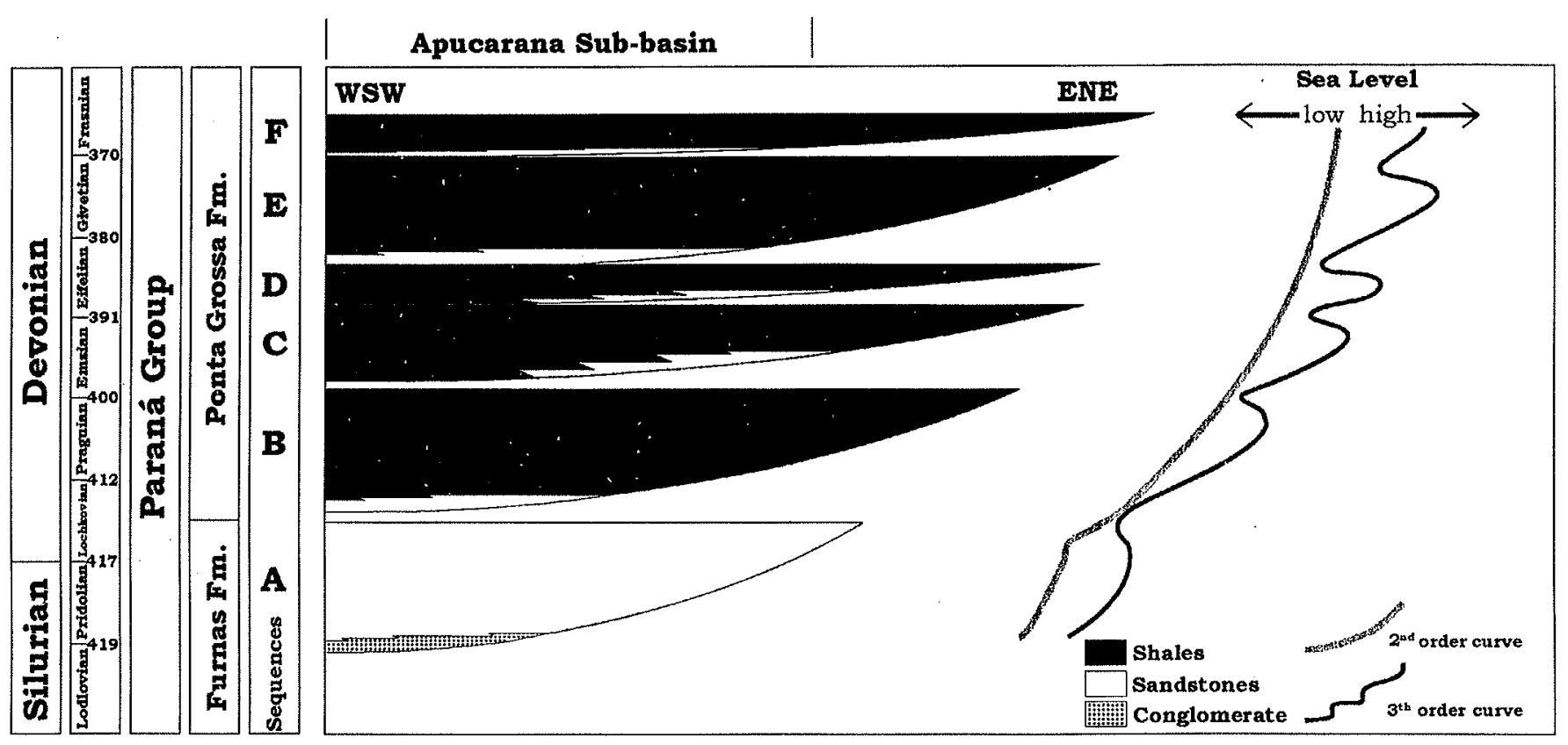

Figure I-Sequence stratigraphy scheme for Ponta Grossa Formation (Bergamaschi 1999), Apucarana Sub-Basin.

The fossils here analyzed occur in sediments of the basal portion of the Ponta Grossa Formation (Sequence B of Bergamaschi 1999), represented by siltstones and mudstones of Pragian age (Grahn 1997, in Bergamaschi 1999), deposited under platformal (shoreface) and shallow-marine conditions (Bergamaschi 1999). The examined succession of the Ponta Grossa Formation is located at the classical Jaguariaíva-Arapoti railroad exposures (Lange \& Petri 1967) (Figs. 2, 3). Sediments are locally represented by 90 meters shales and siltstones with centimetric ferruginous concretions (Melo 1988, Ciguel 1989), deeply bioturbated (Fernandes 1999, Simões et al. 1999, Bergamaschi, 1999), mainly deposited near or below of storm wave base (Simões $e t$ al. 1998a, b). Bivalves, inarticulate (lingulids, orbiculoids) and articulate brachiopods, trilobites (calmoniids, homalonotiids), cephalopods and tentaculits are typical in these sediments (Clarke 1913, Cooper 1977, Popp 1985, Bosetti 1989, Ciguel 1989, Quadros 1987, Kotzian 1995, Machado 1999, among others).

MATERIAL AND METHODS Conulariids were collected in two neighboring outcrops along the Jaguariaíva-Arapoti railroad cuts at $\mathrm{km}$ 2.7 and km 3.4-3.5, at the Jaguariaíva county, Paraná State (Figs. 2, 3). These outcrops were detailed studied by Lange \& Petri (1967), Melo (1988), Ciguel (1989) and Bergamaschi (1999). Nearby exposures of the studied sediments at the Jaguariaíva-Arapoti highway were also examined for conulariids, but no additional specimens were found. Bulk samples included 28 oriented blocks $\left(-5400 \mathrm{~cm}^{3}\right)$ of the Ponta Grossa shales that were taken from two $\sim 4 \mathrm{~m}$ thick interval where numerous conulariids were found. In this intervals conulariids are abundant in some bedding planes (see also Melo 1988), mainly vertically oriented. Blocks yielded 29 specimens. They were sectioned and the conulariid modes of occurrence bedding-plane bioturbation indices (Miller and Smail's indices, Miller \& Smail 1997) and other sedimentologic features noted.

All conulariids were preliminary attributed to the genus Paraconularia Sinclair, 1940. Recently, J.M. Leme (Instituto de Biociências, UNESP, Botucatu) began a taxonomic study of these conulariids, but no formal data is available yet. The morphological terms herein adopted follows Babcock \& Feldmann (1986a). Specimens studied herein are housed in the Scientific Collection of "Laboratório de Paleozoologia Evolutiva, Departamento de Zoologia, Instituto de Biociências, UNESP, Campus de Botucatu", Botucatu, São Paulo, numbers DZP/3073-3085, 3314-3325 and 3327-3331.
TAPHONOMIC ANALYSIS Specimens of conulariids are almost complete and inflated, and crushed or compressed specimens (see Feldmann \& Babcock 1986, for an example) were not observed. Generally, the apex of the examined conulariids is not preserved. Healed injuries (Mapes et al. 1989) on conulariids exoskeletons were not observed. Conulariids remains are associated with brachiopods and bivalves, mainly nuculoids and anomalodesmatans. Almost all conulariids; lingulids and orbiculoids typically retain their calcium phosphatic exoskeletons (see Babcock et al. 1987b, for similar examples). On the other hand, bivalves, articulate brachiopods and trilobites that are present in the same interval are preserved as decalcified molds. External molds of conulariids also occur, but they are present in those samples that were taken directly from the outcrop wall, being deeply weathered.

The following distinct types of occurrence were recognized considering the oriented material (Fig. 4): Vertically oriented conulariids $(n=10)$ with aperture-up, $90^{\circ}-70^{\circ}$ to the bedding plane, in massive siltstones or with incipient lamination, sometimes with isolated, discrete trace fossils (bioturbation index 2). Almost without exception, fossils of mobile organisms, as trilobites, that are common in the examined succession, were not found in the same bedding planes of the vertically oriented conulariids. Inclined oriented conulariids $(n=8)$ with aperture-up, $60^{\circ}-20^{\circ}$ to the bedding plane, in siltstones with isolated traces fossils (e.g., Zoophycus) or zones of generalized disruption (bioturbation index 2 or 3 ). Horizontally oriented conulariids $(n=11)$ in a completely bioturbated siltstone (bioturbation index 3 or 4$)$ or disperse in a thin $(7 \mathrm{~cm}$ thick) shell pavement $(45 \mathrm{~cm}$ long) formed by chaotically oriented brachiopod shells. The paleoecological and paleoenvironmental implications of these preservational modes are discussed below.

DISCUSSION Paleobiological implications Based on their functional morphology and/or phylogenetic inferences, conulariids were interpreted as either planktonic, pseudoplanktonic or benthic invertebrates ( $c f$. Babcock 1991, Van Iten 1991a). The vertically and inclined oriented specimens are interpreted as in situ occurrences, probably representing conulariids buried in life position. In fact, Petri \& Fúlfaro (1983) were probably the first authors to interpret such occurrences as in situ records of conulariids. Although attachment was not observed in the examined material [ $c f$. attached specimens to hyolithid mollusks in Babcock et al. (1987b), although 


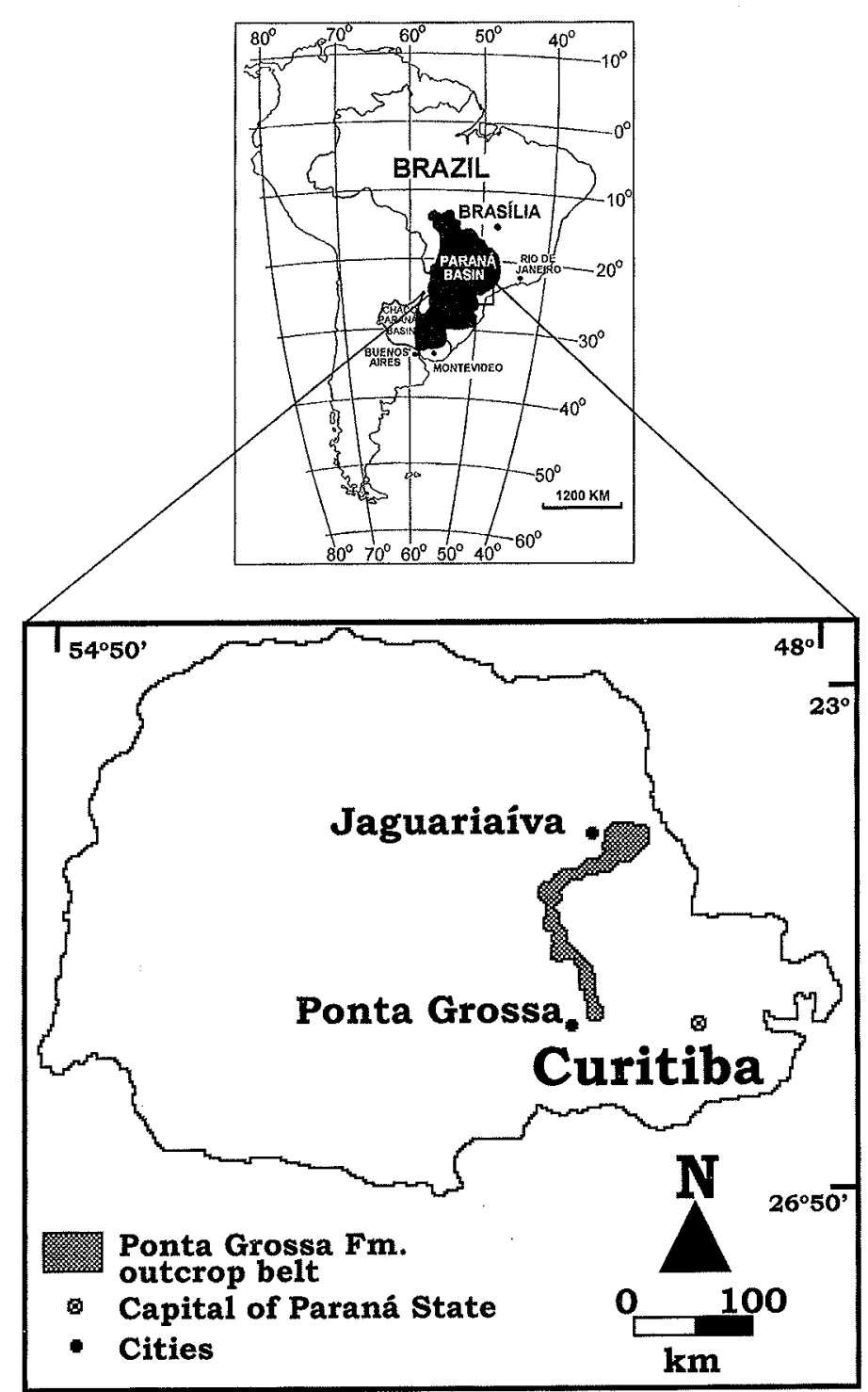

Figure 2 - Location map of the studied area, Jaguariaiva region, Paraná State.

those authors also pointed out the possibility of dispersal through planktonic larvae in the group], its vertical and oblique orientation (aperture-up), related to the bedding plane, is difficult to reconcile with a planktonic mode of life (see also Harland \& Pickerill 1987). Since all examined specimens (vertically or inclined) are aperture-up oriented, this attitude is extremely unlikely to explain as an accidental relationship. Rather, this type of preservation suggests that the conulariids were basally attached to the substrate (apex-down) (see Bischoff 1978). This taphonomic evidence is in accordance with the observations of Sinclair (1948), Finks (1955), Babcock et al. (1987b), Van Iten $(1991 \mathrm{a}, \mathrm{b})$, Van Iten \& Cox (1992). Thus, the studied conulariids are interpreted as benthic, sessile, and epifaunal organisms attached or anchored to the substrate (Fig. 5) (see Harland \& Pickerill 1987). Several authors (Babcock et al. 1987b, Van Iten 1991b, Van Iten \& Cox 1992 and references therein) have observed clusters of

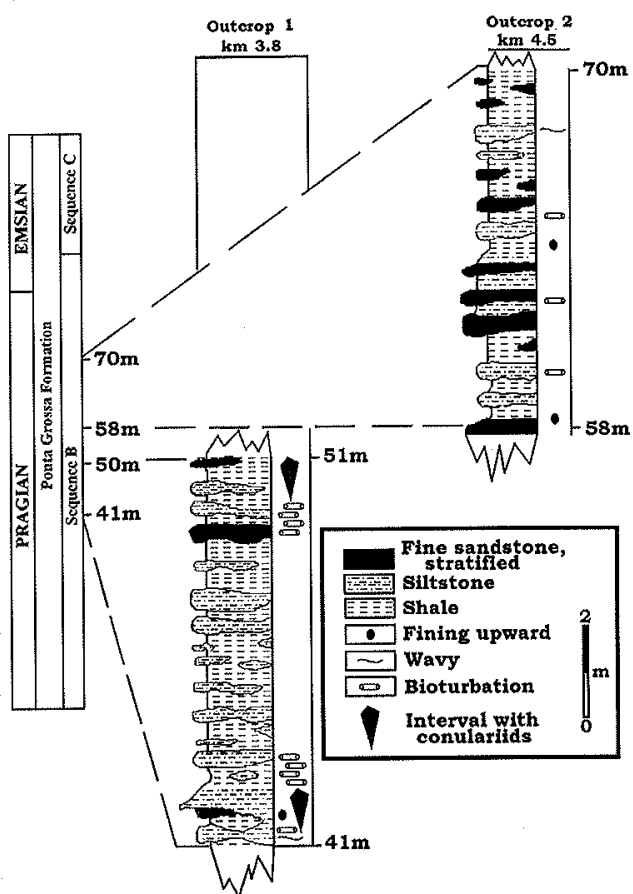

Figure 3-Columnar section of the basal portion of the Ponta Grossa Formation representative of the Sequence B deposits (lithostratigraphically correlated to Jaguariaiva Member), at Jaguariaiva-Arapoti railroad, Jaguariaíva, Paraná State (modified of Popp et al. 1996).

conulariids arising from a common center. Our specimens seems, however, to be solitary individuals. When the specimens were preserved in the same horizon the distance between them varies from a few centimeters $(<20 \mathrm{~cm})$ to several meters $(>2 \mathrm{~m})$. The only exception is the specimen (DZP/3081) that are represented by two individuals vertically oriented and preserved together. Unfortunately, the apical end is not preserved in this specimens, an usual situation for the conulariid fossil record (see, for example, Van Iten \& Cox 1992). Thus, the examined material can not offer new insights to the problem of the nature of monospecific conulariid clusters (gregarious or colonial behavior). However, is noteworthy that the specimens preserved in the referred sample (DZP-3081) are morphologic distinct of the recorded type (Paraconularia sp.) of the Ponta Grossa sediments. This could suggest that different taxa among the conulariids have distinct behaviors (solitary or gregarious/colonial), as well as observed in presumably related groups of cnidarians ( $c f$. Marques 1997). Finally, but not least, the horizontally oriented specimens (parallel to bedding plane) include disrupted, sometimes slightly transported individuals from their original life position by biologic (bioturbation) or sedimentologic agents, as discussed below.

Sedimentologic implications In general, conulariids are rare elements of the fossil record and their common occurrence in some particular strata (commented above) is usually attributed to unusual preservational circumstances. Because their calcium phosphate and protein exoskeleton is very delicate and subject to rapid decomposition upon death of the animal, that circumstance involves rapid sedimentation ( $c f$. Feldmann \& Babcock 1986, Babcock et al. 1987b). The examined shales and siltstones of the basal portion of the Ponta 


\section{Conulariid Orientation}
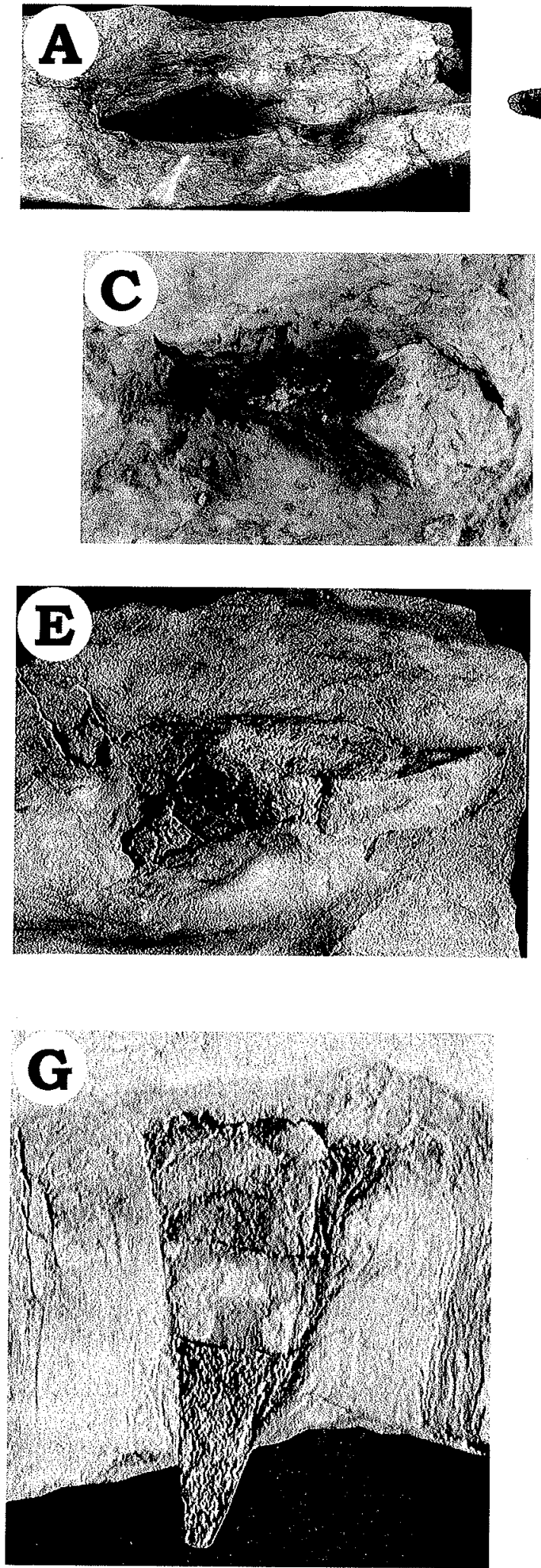
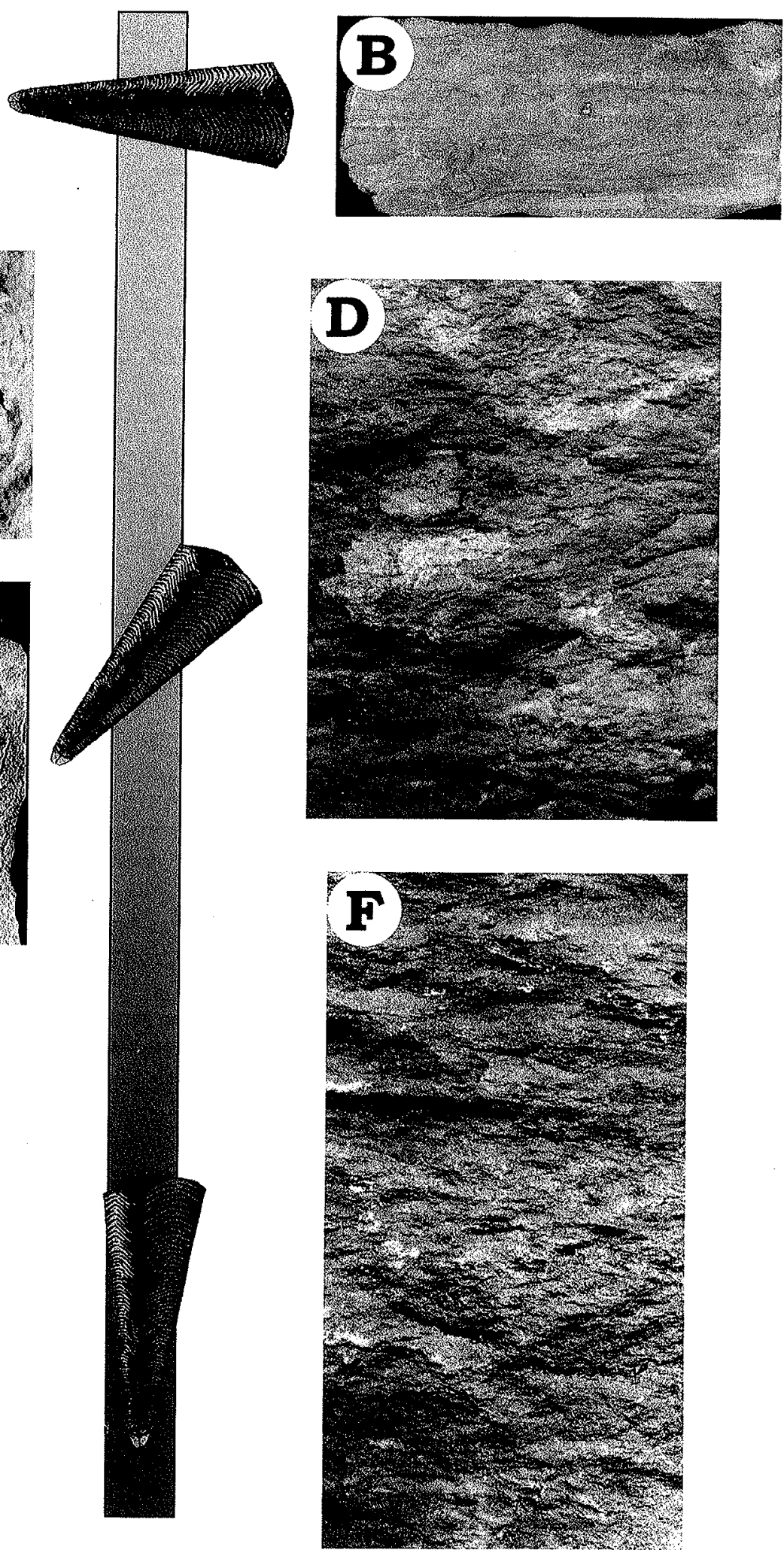

Figure 4 - Modes of preservation: A-Horizontally oriented conulariid; B-Section of the same sample showing the completely disturbed bedding-planes; $C$ Horizontally oriented conularid, $D$ - Same sample of $E$, showing the original bedding disturbed, E-Inclined oriented conulariid with aperture-up; F-Siltstone showing a low degree of bioturbation with vertically oriented conulariid $(G)$. 


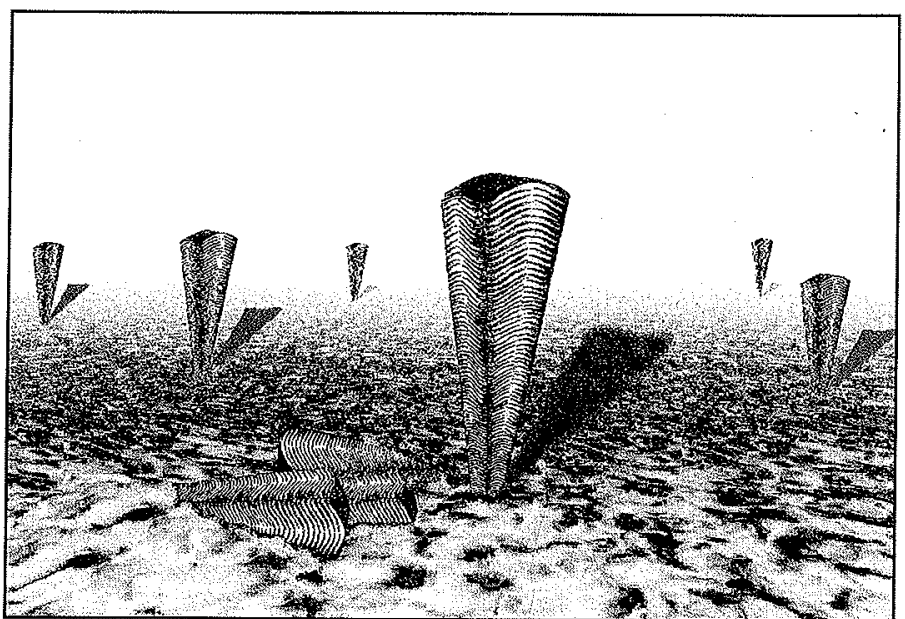

Figure 5 - Hypothetical reconstruction of the conulariid organism, as suggested by their taphonomy.

Grossa Formation include various thin (up to $10 \mathrm{~cm}$ ) obrutionary horizons or tempestite beds (Ciguel 1989, Anelli et al. 1997, Simões et al. 1998a, b) sometimes recording at least 5-8 stacked burial layers (Simões et al. 1998a, b). These were deposited in a muddy shelf, most likely under shallow (shoreface-offshore) and quiet water conditions (Cooper 1977, Melo 1988, Ciguel 1989, Bergamaschi, 1999), but episodically disrupted by storm events (Anelli et al. 1997, Simões et al. 1998a, b, Bergamaschi 1999). Thus, the fossiliferous muddy siltstones with life positioned epifaunal, sessile invertebrates (e.g., conulariids) appear to be silt mud layers that were deposited by density currents slightly below storm wave base. These burial horizons appear to be widespread on a scale of tens of meters. This is because $5 \mathrm{~km}$ far toward SW, coeval sediments (Ciguel 1989), also include bivalves (anomalodesmatans) and clusters of epifaunal articulate brachiopods (Australospirifer iheringi) preserved in life position (Anelli et al. 1997, Simões et al. 1998a, b, 1999).

According to Kondo (1997), the preservation of epifaunal species in mudstones in live orientation could be interpreted in two alternative ways: an accidental death due to rapid burial (1), or normal death in their preferred habitat (2), generally in the absence of burrowing organisms (Feldmann \& Babcock 1986, Harland \& Pickerill 1987). The first seems to be the case of the vertically oriented conulariids that were preserved in life position. In this context, the obrution beds described above are interpreted as the result of distal mud tempestites in quite shelf environment that was not accompanied by a significant increase in hydraulic energy. Since at least 5 of these burial horizons where found, being stratigraphically separated by tens of meters, the examined section of Ponta Grossa Formation could be a condensed section. In fact, some taphonomic (e.g., epifaunal organisms preserved in life position), stratigraphic (e.g., transgressive pulse), and sedimentologic features (e.g., a thick shale sequence with several stacked obrution beds), as well as the paleogeography (e.g., shallow epeiric muddy sea strongly influenced by episodic storms) are, in general, similar to those of the Silurian beds from the "Homocrinus Beds" of western New York and southern Ontario (Brett 1983). Brett \& Taylor (1997) interpreted these as generated by storm events in shelf environments (up to $30 \mathrm{~m}$ ). This environmental context is very similar to those suggested by Ciguel (1989) and Bergamaschi (1999) for the basal portion of Ponta Grossa Formation based on stratigraphic and sedimentologic evidences.

Finally, the inclined and horizontally oriented conulariids are also in situ records, but taphonomically altered mainly by the biological activity within the substrate. On the other hand, the conulariids that are also horizontally oriented, but associated to a thin shell pavement of Australospirifer iheringi shells are fully inflated, non-crushed, also indicating their rapid burial after a short period of time at the sedimentwater interface by hidraulic agents (storm currents or flows).

CONCLUDING REMARKS Vertically oriented specimens (aperture-up) are interpreted as autochthonous elements, indicating the abrupt burial of living invertebrates. Thus, an attached epifaunal mode of life is inferred for these specimens. Horizontally oriented specimens correspond to disrupted elements, particularly by the biological activity within the substrate, during and after the rapid sediment deposition, associated to storm events. These indicates that conulariids can be found in sediments with high bioturbation index ( $c f$. Feldmann \& Babcock 1986, for a different view). Specimens vertically preserved directly adjacent to horizontally oriented conulariids in zones of intense sediment bioturbation support this idea. In this case, even the horizontally oriented specimens are reliable indicators of changes in siliciclastic accumulation rates, in tempestite proximality, and postmortem alteration by biological agents, specially when the inorganic primary sedimentary structures are lacking or were completely destroyed or obliterated by the biological activity in the substrate. The fossiliferous sediments of the basal portion of Ponta Grossa Formation rich in conulariids are interpreted herein as tempestite beds.

Acknowledgements We would like to thank MSc. Renato P. Ghilardi and MSc. Fernanda Torello for their field assistance. Dr. Luiz E. Anelli for providing additional specimens of IG-USP for analysis FAPESP (96/9708-9), FUNDUNESP (331/99-DFP) and CNPq (301023/94-8) supported the study, in part. This is a contribution to the projects (FAPESP 99/10824-1, 99/10823-5, 96/10544-0, 97/04572-4). To two anonimous referees of RBG for the review and suggestions to the manuscript.

\section{References}

Anelli LE Simōes MG , Lucio MP 1997 Brazilian bivalves from the Emsian Australocoelia community preserved in sinu. An. Acad. Bras. Ci., 69:280-281.

Assine M.L., Soares P.C., Milani E.J. 1994. Seqüências tectono-sedimentares mesopaleozóicas da Bacia do Paraná, Sul do Brasil. Rev. Bras. Geociências, 24(2):77-89

Babcock L.E. 1988. New Permian conulariids from Devon Island, Canada. Journal of Paleontology; 62(4):615-619.

Babcock L.E. 1991. The enigma of conulariid affinities. In A.M. Simonetta \& S.C. Morris (eds.) The early evolution of Mefazoa and the significance of problematic fossil taxa. Cambridge University Press, 113-143.

Babcock L.E. \& Feldmann R.M. 1984. Mysterious fossils. Earth Science, 37(3):16-17.

Babcock L.E \& Feldmann R.M. 1986a. Devonian and Mississipian conulariids of North America. Part A. General discription and Conularia. Annals of Carnegie Museum, 55:349-410.

Babcock L.E. \& Feldmann R.M. 1986b. Devonian and Mississipian conulariids of North America. Part B. Paraconularia, Reficulaconularia, new genus and organisms rejected from Conulariida. Annals of Canegie Museum, 55:411-479.

Babcock L.E. \& Feldmann R.M. 1986c. The phylum Conulariida. In A. Hoffman \& M.H Nitecki (eds.) Problematic Fossil Taxa. Oxford University Press, 135-147.

Babcock L.E., Feldmann R.M., Wilson M.T. 1987a. Teratology and pathology of some Paleozoic conulariids. Lethaia, 20:93-105.

Babcock L.E. Feldmann R.M. Wilson M.T. Suárez-Riglos M. 1987b. Devonian conulariids of Bolivia. National Geographic Research, 3:210-231.
Babcock L.E., Gray J., Boucot A.J., Himes G.T., Siegele P.K. 1990. First Silurian conulariids from Paraguay. J. Paleontol., 64:897-902.

Bergamaschi S. 1999. Análise estratigráfica do Siluro-Devoniano (Formações Furnas e Ponta Grossa) da sub-Bacia de Apucarana, Bacia do Paraná, Brasil. Inst. de Geociências, Universidade de São Paulo, São Paulo. Unpublished Ph.D. Thesis, $167 \mathrm{p}$.

Bischoff G.C.O. 1978. Internal structures of conulariid tests and Coconulariina n. suborder (Cnidaria, Scyphozoa). Senckenbergiana lethaea, 59:275-327.

Bosetti E.P. 1989. Revisão sistemática dos Lingulida (Brachiopoda: Inarticulata) da Formação Ponta Grossa (Devoniano), Estado do Paraná, Brasil. In SBG, Congr. Bras. Geol., 11, Curitiba, Anais, 1:73-89.

Brett C.E. 1983. Sedimentology, facies and depositional environments of the Rochester Shale in western New York and Ontario. J. Sed. Petrol., 53:947-971.

Brett C.E. \& Taylor W.L. 1997. The Homocrinus Beds: Silurian crinoid Lagerstätten of western New York and Southern Ontario. In C.E. Brett \& G.C. Baird (eds.) Paleontological Events: stratigraphic, ecological, and evolutionary implications. Paleontological Events: stratigraphic, ecologica,
Columbia University Press, New York, 181-223.

Ciguel J.H.G. 1989. Biosesmatigrafia dos Tentaculoidea no flanco oriental da Bacia do Paraná é sua ocorrência na América do Sul (Ordoviciano-Devoniano). Inst. de Geociências, Universidade de São Paulo, São Paulo. Unpublished M.Sc. Dissertation, $237 \mathrm{p}$

Clarke J.M. 1899. A fauna siluriana superior de Rio Trombetas, Estado do Pará, Brazi Archivos do Museu Nacional do Rio de Janeiro, 10:1-48. 
Clarke J.M. 1913. Fóssejs devonianos do Pạaná. Monografias do Servico Geológico e Mineralógico do Brasil, 1:1-353.

Devonian of Brazil and the Frasnian-Famennian mass extinction. Palaeogeos. Palaeoclimatol., Paloeoecol., 21:165-207.

Feldmann R.M. \& Babcock L.E 1986. Exceptionally preserved conulariids from Ohioreinterpretation of their anatomy. National Geographic Research, 2:464-472.

Fernandes A.C.S. 1999 Conteúdo icnológico das formaçōes do Ordoviciano-Devoniano da Bacia do Paraná, Brasil. Bol. Museu Nacional, 46:1-12

Finks R.M. 1955. Conularia in a sponge from the West Texas Permian. J. Paleont. $29(5): 831-836$

Harland T.L. \& Pickerill R.K. 1987. Epizoic Schizocrania sp. from the Ordovician Trenton Group of Quebec, with comments on mode of life of conulariids. J. Paleont. 61(4):844-849.

Jerre F. 1994. Anatomy and phylogenetic significance of Eoconularia locuta, a conulariid from Silurian of Gotland. Lethaia, 27:97-109.

Kondo $Y$ 1997. Inferred bivalve response to rapid burial in a Pleistocene shallow-marine deposit from New Zealand. Palaeogeog., Palaenclimatol., Palaeosecol., 128:87-100.

Kotzian C. B. 1995. Estudo sistemático e morfo-funcional de bivalves (Mollusca) das Formaços Vila Maria (Siluriano) e Ponta Grossa (Devoniano), Bacia do Paraná, maçós. Vila Maria (Siluriano) e Ponta Grossa (Devoniano), Bacia do Pâncias, Brasil: interpretafäo do regime hidrodinamico-sedimentar. Inst. de Geociencias,

Lange F.W. \& Petri S. 1967. The Devonian of the Paraná Basin. In J. J. Bigarella, (ed.) Problems in Brazilian Devonian Geology. Bol. Paranaense de Geociências, 21 $22: 5-55$

Machado D.M.C. 1999. Nuculites Conrad, 1841 (Mollusca, Bivalvia): sistemática e implicaçós paleobiogeográfica. Inst. de Geociências, Universidade Federal do Rio Grande do Sul, Porto Alegre, Unpublished Ph.D. Thesis, $298 \mathrm{p}$

Machado D.M.C. \& Fonseca V.M.M. 1997. First occurrence of Conulariida in the Middle Devonian of Amazon Basin (Maecuru Formation), Northern Brazil. In SBP, Congr. Bres. Paleont 15, Săo Pedro, Boletin de Resumos, p. 42

Mapes R.H., Fahrer T.M., Babcock L. 1989. Sublethal and lethal injuries of Pennsylvanian conulariids from Oklahoma. J. Paleont., 63:34-37.

Mariñelar M. P 1970. Algunas especies de Paraconuluria Sinclair del "Sistema de Tepuel" (Chubut) y sus relaciónes com faunas del hemisferio austral. Ameghiniana, 7:139-150.

Marques A C 1997. Evoluçōo basal nos Metazoa, com ênfase nas relaç̃es entre os Cuidaria. Inst de Biociências, Universidade de São Paulo, São Paulo. Ph.D. Thesis, $415 \mathrm{p}$.

Melo J.H.G de. 1988. The Devonian System. In J.C. Castro (ed.) Sedimentology Stratigraphy and Paleontology of the Gondwana sequence of the Parana Basin. Guide Book, Excursion A2, Seventh Gondwana Symposium, São Paulo, 4-9.

Miller M.F. \& Smail S.E. 1997. A semiquantitative field method for evaluating bioturbation on bedding planes. Palatios, 12:391-396.

Oliveira A.I. \& Leonardos O.B. 1943. Geologia do Brasil. Serviço de Informação Aglícola Brasil, Série Didática, 2:1-813.

Pereir E Bergamaschi S. Rodrigues M.A. 1998. Sedimentary evolution of the Ordovician, Silurian and Devonian sequences of Paraná Basin in Brazil Zentralblott für Geologie und Palaiontologie, 1:779-792.
Petri S. \& Fúlfaro V.J. 1983. Geologia do Brasil: Fanerozóico. Säo Paulo, EDUSP. 631 p.

Popp M.T.B. 1985. Revisão dos trilobitas calmoniídeos e comunidades faunísticas da Formação Ponta Grossa, Devoniano do Estado do Paraná. Inst. Geociências,

Popp M. B. Coimbra J.C. Hauch A. 1996. Revisão do gênero Paracalmonia Struve, 1958 (Pro Probolites Clarke, 1913), Trilobita - um ensaio em sistemática filogenética. Gaia, 12:19-32.

Quadros R. 1987. Paleontologia dos Brachiopoda-Lingulida, Strophomenida, Spiriferina Terebratilida - devonienos, da Serra de Atimã e arredores, Mato Grosso. Brasil. Inst. de Geociências, Universidade
Unpublished Ph.D. Thesis, 87p.

Sabattini N. 1986. Distribución geográfica y estratigráfica de los Cnidaria y Bryozoa del Carbonífero y Pérmiço de la Airgentina. Revista del Museo de la Plata (N.S.), 9:117.

Schneider R L. Muhlmann H., Tommasi E., Medeiras R.A., Daemon R.F., Nogueira A.A. 1974. Revisão estratigráfica da Bacia do Paraná. In SBBG, Congr. Bras. Geol., 28, Porto Alegre, Ancis, 1:41-65.

Simões M.G., Kowalewski M., Torello F.F., Anelli L.E. 1998a. Long-term time-averaging despite abrupt burial: Paleozoic obrution deposits from epeiric settings of Paran Program, p. A-384.

Simões M.G., Torello FF, Kowalewski M., Klein C., Mello L.H.C., Ghilardi R.P. 1998b. Are the obiution deposits the most precise and best-resolved beds in event stratigraphy? Some Paleozoic examples from the Paraná Basin, Brazil. In SBG, stratigraphy? Some Paleozoic examples from the Para

Simōes M.G. Marques A.C., Mello L.H.C., Ghilardi R.P. 1999. Does the preservational potential play a role in cladistic analysis? In SBP, Congr. Bras. Palcont., 16, Crato, Resumos, p.110.

Sinclair G.W. 1948. The biology of the Conularia. Ph.D. thesis, McGill University, Montreal, Quebec. $442 p$

Van Iten H. 1991 a. Evolutionary affinities of conulariids. In A.M. Simonetta \& S.C. Morris (eds.) The early evolution of Metazoa and the significance of problematic fossil taxa Cambridge University Press, 145-155.

Van Iten H. 1991b. Anatomy, patterns of occurrence and nature of the conulariid schott. Palaeontology: 34:939-954.

Van Iten H. \& Cox R.S. 1992. Evidence of clonal budding in a radial cluster of Par. \&enthaia 25:421-426. Paracomulartacis IS (Whice 1991 Zalán P.V., Wolf S., Vheira Symposium, 7, São Paulo, Proceedings, 83-117.

Manuscrito A-1143

Recebido em 31 de janeiro de 2000

Revisão dos autores em 25 de abril de 2000 Revisão aceita em 30 de abril de 2000 